essentially a State question. It will be solved in each State in the light of the traditions and experience of that State, but the goal should not be misunderstood. The aim is not to burden the citizen with unnecessary political activity. It is not to leave the party voters impotent to fight despotism and corruption within the party, because of the extreme difficulty in dislodging unfaithful party leaders. It is in giving to the party voters the checks upon leadership which will make it responsible and put it under control, while at the same time preserving the opportunities for party conferences and avoiding unnecessary contests within the party in order that, in the endeavor to secure freedom from intolerable abuses, the efficiency and reasonable requirements of party organization should not be impaired.

\title{
AN AMERICAN GARDEN CITY ${ }^{1}$
}

\author{
BY THOMAS ADAMS \\ Town Planning Adviser to the Canadian Government
}

A garden city is newly built from the ground up. It is planned to secure maximum economic returns, beauty, health and recreation. Proper balance is maintained between residential, recreational, industrial and agricultural areas. It pays its own way. :: ::

A garden city is needed in America as a practical object lesson in solving many problems in connection with the building of cities and towns. Those who question that need are welcome to their enjoyment of the exhibition of waste, incompetence and muddling which is provided by the modern city. On the whole the industrial community is probably the worst product of civilization in all countries-and we have nothing much better to show in that regard in the United States and Canada than in some of those countries we call decadent.

\section{THE LETCHWORTH GARDEN CITY}

Before entering upon a statement of how and where to establish a garden city in America I must show what I mean by a garden city by giving an

I A paper delivered before the Sixteenth Annual Convention of the American Civic Association at Amherst, October 14, 15 and 16, 1920. outline of the history and standing of the English Garden City at Letchworth:

The garden city movement was started in England as a result of a book written by $\mathrm{Mr}$. Ebenezer Howard, published in 1898. Only two experiments have been initiated on the lines advocated by Mr. Howard. The first is at Letchworth and the second at Welwyn, both in Hertfordshire, England. The most advanced scheme and the one which is best known is the first garden city at Letchworth.

For the purpose of starting this scheme on the principles advocated by Mr. Howard, a number of separate properties were purchased in 1903, comprising a total area of 3,818 acres; an additional area of 750 acres has since been acquired. This land was purely agricultural in character, although two or three small villages or hamlets, occupied mostlybyagricultural labourers, were situate on the estate at the time of its purchase. An essen- 
tial part of the scheme is that a portion of the land shall be retained permanently for agricultural purposes and shall not be used for urban development. About 1,300 acres or onethird of the original Letchworth Estate have been set apart for the building of the town and for open spaces, and the remaining 2,518 acres, now increased to 3,268 acres, have been definitely reserved for agricultural purposes.

These particulars of the scheme indicate that among its fundamental features are:

1. The purchase of an agricultural estate unhampered by existing urban development on which to establish an industrial and residential town, principally by securing as a first step a concerted movement of manufacturers from congested centres.

2. The restriction of the area set apart for the building of the city in such a way as to retain a large proportion of the site for agricultural purposes.

Starting with a purely agricultural property and with these two objects in mind the garden city company had the advantage of being able to experiment in the system of land tenure that would encourage the use of land, instead of the exploitation of those who use it, and to plan the area for the purposes of promoting health, industrial efficiency, financial soundness and amenity.

In order to carry out the above objects it was necessary to impose regulations regarding the disposal of the land and to limit the amount of profit that could be derived by those who provided the capital. At Letchworth, the land was leased for 99 years to the person building a house or factory, with the right of renewal for further periods of 99 years, and I believe there are some cases where factory sites have since been leased for
999 years. The system of leasehold tenure is not sufficiently understood on this continent to make it likely to be acceptable. It is probable that some system of ownership will have to be devised, with proper restriction attached, if a scheme were started in Canada or the United States.

With regard to the finance of the Letchworth scheme, the following summary gives a rough idea:

Total cost, approximately, $\$ 680,000$.

Capital, company shares, loans, mortgages, etc., approximately in $1919, \$ 2,600,000$.

Gross value of land and undertakings in 1919, $\$ 3,400,000$.

Cost per acre, $\$ 225.00$.

Value of buildings, timber, etc., $\$ 125.00$ per acre.

Net cost per acre, $\$ 100.00$.

Distance from London, 33 miles.

Population 1903, 450; 1920, approximately, 10,000 .

Number of inhabited houses, factories, etc., 2,500.

Different kinds of industries, 30.

Ultimate population aimed at, 35,000 .

Ground rents, $\$ 44,000$.

Ground rents capitalized, $\$ 880,000$.

There are gas works, electric power works, water supply works, sewage disposal system and other public services. When the estate was purchased there was considerable mileage of existing roads. Since then, ten miles of new roads, twenty miles of water mains, fifteen miles of gas mains and fourteen miles of sewers have been laid.

The following points should be noted:

1. The garden city form of development has the advantage of avoiding the evils incidental to single industry towns. Letchworth has a greater variety of industries than the average town and one of the objects aimed at by its promoters is to secure this variety so as to employ different kinds of labour.

2. It provides also for the inter- 
mingling of those engaged in manufacture and agriculture.

3. It is a self-contained town and not a mere dormitory suburb and should not be confused with smaller experiments or with single industry towns.

4. By mixing industries and mingling town and country life you not only get more healthy conditions but reduce the waste of time and money in conveying passengers between the home and the place of employment and also in the cost of distribution of food.

5. By limiting the dividends of those who provide the capital and by preventing speculation in land, the whole of the increment of value created by the conversion of an agricultural site into a building site for a town, together with the profits made by public services, can be used for the benefit of the city and the inhabitants.

The interest on mortgages and debentures has been regularly paid but there are arrears of accrued interest amounting to about $\$ 830,000$ on ordinary shares.

The question of the financial results is important but too much reliance should not be placed on any criticism of the scheme based on the mere facts regarding the dividends paid at Letchworth. The scheme has suffered very considerably from lack of capital and its chief drawback, from a commercial point of view, has been the fact that the directors have continually had to work from hand to mouth in obtaining the funds necessary to develop the city. Moreover, they have been doing a unique thing and have naturally made the errors of pioneers. They have paid for experience that is available as an asset to others who follow. The death rate in Letchworth in 191819 was 10 per 1,000 , the infantile death rate 30 per 1,000 births, and the birth rate 17.5 per 1,000 .

The above is a brief outline of the English experiment in creating a gar- den city for the purpose of indicating first, the main underlying principles of the scheme and, second, a few of its financial features.

\section{THE LETCHWORTH SCHEME NOT A PATTERN TO BE RIGIDLY FOLLOWED}

In considering the establishment of a garden city in the United States or Canada we should keep these principles and financial features in mind but should not regard them as committing us to any definite policy or form of development. The Letchworth scheme has shown what to avoid as well as what to imitate-that is the value of an experiment. It has had some administrative weaknesses. It has shown that it is necessary in starting a scheme to have sufficient capital to purchase the site and cover the cost of preliminary developmentand that it is desirable to have additional capital to cover some of the cost of building houses and factories. Had the directors of the Letchworth scheme been able to raise $\$ 2,000,000$ to $\$ 3,000$,000 at the outset their task would have been enormously simplified and everything that has happened points to the probability that, in such an event, the city would be now near completion and would be paying full dividends on ordinary stock.

Another defect in administration of the Letchworth scheme is that a large board of directors has tried to do too much of the management and has not entrusted sufficient power to a paid executive. Nor has the board striven hard enough to obtain sympathetic co-operation from the residents.

In regard to general principles on which the scheme was promoted experience has shown that these were sound, to meet English conditions.

It does not follow that they are 
sound in every respect to meet American conditions, or that the Letchworth scheme is a mould to be used for stereotyping all other garden cities. The future success of this form of development will depend on the common sense applied to adapt it to suit different circumstances, laws, and conditions. It is capable of elasticity, subject to a few fundamental principles that are easily defined. Although it would be fatal to treat any one scheme as a pattern for others there must be adherence to the following principles in all schemes professing to be garden cities:-

First:-Delimitation of part of the area acquired for the scheme as a site for the city proper and of part as an agricultural belt round the city. Second:-Provision for a manufacturing section to provide employment for the bulk of the residents of the city.

Third:-Planning of the whole urban and rural sections in advance of development, with a view to securing ample air and garden space and good surroundings for the homes, parks and other recreation spaces, efficient means of transportation and other facilities for the industries, convenience for traffic, and economic use of the land.

Fourth:-Limitation of the dividend payable on capital subscribed by investors, and of the profit which may be made by means of speculation in land and buildings by companies or individuals.

The application of these principles in detail may differ in different schemes. At Letchworth about 1,300 acres are set aside for a city of 35,000 and 3,218 acres or nearly 72 per cent for a permanent agricultural belt. In another scheme a larger or smaller area may be determined for the site of the city, or for the agricultural belt.

At Letchworth the aim is to have an average of eight houses to the acre but that does not mean that this is the ideal number. Then the dividend payable may be six or seven per cent instead of five as at Letchworth; or the land may be sold to individual purchasers instead of let on lease if adequate measures can be taken to prevent change of use, or injurious use and speculation.

Objection may be taken by many to any suggestion that the land should be sold. Personally I would not support such a suggestion in an English scheme because English people are accustomed to leasehold tenure and it has great advantages over freehold in connection with the administration of the scheme. Some of the directors of the Letchworth scheme have been favourable to selling land on the ground that this would provide them with much ready capital. But the fact that the company has not parted with any of the freehold means that the whole increase in the value of the land is accruing for the benefit of the community. It is not, however, an essential part of a garden city that the land be let on leasehold and in a country where freehold is customary it may be necessary to sell the land to individual users. More care would have to be taken, however, with a system of freehold ownership than with leasehold tenure, in imposing restrictions on use and speculation, partly under deed of sale and partly under a zoning ordinance. I have come to believe that the advantages of private ownership of land by persons occupying and using the land are not to be lightly regarded and I see no objection to such persons enjoying benefit from the values which accrue to such property from their own efforts or expenditures. They should not, of course, benefit from any value which accrues from community expenditures, but that is a matter that can be ad- 
justed by an equitable system of taxation for which the local government is responsible.

The disadvantages of private ownership of land from the point of view of the public welfare are not incident to proper use and occupancy except to the extent that is due to neglect to impose equitable taxation but to nonuse when it is held for speculation, or to abuse or improper use when it is occupied by buildings that are unhealthy or excessive in height or by anything that is a nuisance. This non-use or abuse is preventable by legislation and particularly by city planning legislation, the want of which is the chief cause of the bad results of land ownership.

THE CREATION OF A GARDEN CITY INT AMERICA

Having the above facts and principles in mind how do we proceed to form a garden city? We need a site, but in order to enable us to select the proper site we need to determine first what kind of scheme we propose to carry out. The site should be selected to suit the scheme and not the scheme to suit the site; hence our first task is to determine what the scheme shall be.

Some idea of this has already been given. We should aim at a city larger than Letchworth to secure the social advantages necessary to make a prosperous self-contained community. The area for the city should be large enough to take care of a population of from 50,000 to 100,000 . Let us adopt the former figure for purposes of illustration, and let us assume first that we plan for an average of eight houses or forty persons to each acre, with an industrial area of one-fifth the residential area, and with an agricultural belt twice the size of the whole resi- dential and industrial area. We shall then have:-

\begin{tabular}{|c|c|c|c|}
\hline Residential a & rea & 1,250 & 0 \\
\hline Industrial & “ & 250 & \\
\hline Agricultural & “ & 3,000 & \\
\hline Total & “ & 4,500 & \\
\hline
\end{tabular}

An estate of approximately this size has to be purchased. What should it cost? This will depend on a number of factors which must be known before it can be decided what capital is needed. A property costing $\$ 200$ per acre may be dearer than a property costing $\$ 500$ having regard to its situation and potentialities but it is unlikely that a higher price than $\$ 500$ need be paid. The site need not be immediately adjacent to an existing large city but should be within forty-five minutes by rail from such a city, no matter what the distance may be. It should be accessible to the existing city by good roads and have trolley connection. It will be an advantage to have a waterway but not essential. A supply of power will be needed and if it already exists will be an added asset in valuing the land. An ample water supply will be needed for 50,000 persons and for the factories occupying 250 acres. The site should be capable of being economically drained. An existing station for passengers and freight will be a disadvantage, as stations are usually surrounded by existing buildings and land is accordingly higher in price. It is easy to get a station when the need for it is established. The land should be intersected by at least one good trunk railroad. The land should be fertile and easily cultivated so as to encourage gardening and small farms. There appears to be no question that such a site can be obtained in the United States or Canada at a reasonable price.

In selecting the site and deciding 
what initial development to undertake we have to bear in mind that we must offer sufficient attractions to manufacturers to draw them to the locality. The things a manufacturer needs are those things that at present are causing him to move his works from the crowded cities to the outer suburbs. They are:-

Cheap land and room for getting light and airy buildings as well as for future extensions; reasonable assessment and full value for taxes paid; cheap electric power; good living conditions for workers near to factories; good railway facilities, which include facilities for access to railroads for switching to secure economy in shipping and receiving freight; and absence of congestion of streets. These and other matters should be considered both in selecting the site and preparing the plan.

Another element that should be catered to as a means of helping the city to grow in the early stages is a resident population comprising people who want homes but who work in other places; for instance in the near-by existing city. It is not of primary importance to provide for this class and the garden city should not be built up as a mere dormitory for the bigger community, but it is helpful in getting the city founded to have a good residential section. Moreover, it keeps the new city from becoming entirely industrial and introduces amenities that can only be obtained with good residences. It encourages professional men to come to the city and is indirectly helpful to the establishment of industries as it provides the social attractions needed for masters and managers who are usually not indifferent to their own comfort in selecting a site. For this element there must be provided an area quite free from the smoke and noise of the fac- tory area. Factories in any case should be placed on the side of the town where the prevailing winds blow the smoke away from the central and residential districts. On an estate of 4,500 acres there is ample room for both kinds of development. The placing of parks and parkways would have the effect of separating the two areas. A golf course and good inn are a necessity from the outset. With cheap land, protected surroundings, a pure water supply, good drainage and rapid means of communication to the big centre a magnet would be created strong enough to draw many purchasers of lots on which they could erect good homes.

The garden city would have all the advantages of preventive zoning, with such things as an agricultural belt, which no existing city can acquire. Its taxes would be comparatively low because the things that cost most money in a city would cost little. The park areas would consist of lands least adaptable for building and be set aside as part of the development and their cost merged in the price of the building lots. The wide main thoroughfares would cost nothing extra because they would be complementary to narrow residential roads. Pavements would be economically designed to suit the industrial and residential districts. Concentration of the factory area on the railroads would lessen the cost of transporting goods with its usual double or treble handling and injury to the surfaces of roads. Sewers, water mains, and pavements would not be constructed along great lengths of vacant lots between scattered buildings but would go slightly in advance of building needs.

It has been suggested that the present is not a time to start a garden city because costs of construction are high. But it is precisely while this is the 
case that the real advantages of a garden city can be demonstrated. The savings in development which are possible in a garden city would be proportionately greater in times of high prices than in times of low prices.

\section{QUESTION OF FINANCE}

To establish such a city the very first step to take is to form a pioneer company to draw up a scheme, interview manufacturers likely to move, investigate sites, employ engineering advice re water supply, drainage, etc., and acquire an option of a suitable property. The main company with larger capital should not be formed till the pioneer company has done its work. The pioneer company would require a small capital of $\$ 100,000$ to $\$ 250,000$. Its directors should be men who would command confidence. The co-operation of the press should be secured. All the London papers gave a free advertisement of the prospectus of the Letchworth Pioneer Company. The capital provided for the operations of the pioneer company should bear interest at seven or eight per cent and shares of equal value should be given to the stockholders in the main company when formed. Those who took shares in the pioneer company should have it made clear that the money might be lost if the scheme did not proceed beyond the pioneer stage.

When the sites were selected and some manufacturers persuaded to take sites the next step would be to form a corporation with a capital of $\$ 5,000,000$ to develop the property, build roads, install water, electric power, etc.,and erect the first houses.

The question of site, however, is one for painstaking investigation. That one can be obtained of suitable character and situation I have no doubt. Nor do I think that the problem of getting the needed capital is difficult of solution. The real difficulty is the primary one of getting a number of men with business capacity, courage and high resolve to give their time as directors of a pioneer company, and to raise $\$ 100,000$ to $\$ 250,000$ to carry out the preliminary work of promotion and investigation.

I have said that the main purpose of such a scheme is to be an object lesson for the American continent. The garden city of England is not much of a success as a commercial enterprise for reasons I have given, but these need not apply to a new experiment on this side. It is not a solution of the housing problem but it has been an excellent guide to show how it can be solved. It has revolutionized public opinion with regard to the methods of dealing with the problem of housing. It has created the atmosphere necessary to cause the government of England to pass an effective town planning act. It has proved that a city or town can be created from the foundation upwards and made commercially successful. It has indicated how to solve the land question without confiscation, and with financial benefit to the community equal to what can be obtained by measures that are confiscatory in respect of private rights.

The stock of the pioneer company should be raised in ordinary shares at seven or eight per cent interest, accumulative. Any further capital should be obtained in debentures secured on the property at the lowest interest possible according to conditions in the financial market. The scheme should not be floated with less than $\$ 3,000,000$ or about $\$ 650$ per acre for 4,500 acres.

WHERE THE FIRST SCHEME SHOULD BE STARTED

The first scheme would be by way of experiment as an object lesson. It is essential that it should be located in 
the position most likely to command success. Having regard to all the factors necessary to contribute to that success I think there is no doubt that the best locality would be somewhere on the eastern seaboard of the United States. I believe the people of Massachusetts could establish a successful garden city near Boston. Probably a better site in many respects would be obtainable on the main railroads between Philadelphia and Baltimore. In both localities there are the factors of individual wealth, of existing and overgrown manufacturing centres, of home-loving instincts and habits, pressure of high taxation, congestion of traffic, good railroad and trolley facilities, nearness to ports, good land, beautiful landscape features, a cultured population, and a broad-minded and influential press. The English garden city has done more as an object lesson in a few years to educate the people of England than fifty years of talk about housing. It has shown that the application of science is as essential to the building of a city as it is to the development of industry.

Its economic basis rests on the certain increase in the value of the land due to its conversion from agricultural to building uses. The following paragraph from a report of Dr. Murray Haig consolidates the results of an analysis of the increase of land values created in the city of Gary, Indiana:-

The market value in 1906 of the land in Gary excluding that occupied by the plants of the steel corporation, is estimated at $\$ 6,414,455$, and the present value at $\$ 33,445,900$. The increase in the ten-year period, therefore, amounts to $\$ 27,031,445$. The examination of the value of the services rendered by those who have come into possession of this increment indicates that an allowance of perhaps $\$ 200,000$ should be made for necessary administrative expenses, that not more than $\$ 1,000,000$ should be credited because of taxes advanced on unused lands, and that $\$ 4,025,712.70$ should be allowed as having been paid by land-owners for local improvements. The total money value of the services of these beneficiaries of the increment amounts then to $\$ 5,225,712.70$. The amount of the increment which might conceivably have been conserved is thus found to be $\$ 21,805,732.30$.

The author of this statement admits the possibility of some factors being overlooked, but regards his estimate of increment value as conservative. But even if the value were half the amount given in the estimate, that would be a substantial profit, arising from the creation of a community over a period of ten years.

The investigations made by Dr. Murray Haig and others in the United States show that a fair estimate of the increment of land-value produced by community development, after deducting the value which is attributed to all expenditures for local improvements, etc., is from $\$ 400$ to $\$ 450$ per capita. The assessment valuations of Canadian cities confirm this figure. Taking the lower figure, it may be estimated that the creation of a new town of 50,000 people may create an aggregate increment of value of $\$ 20$,000,000 . To this has to be added the profits realizable from the usual municipal services, including transportation, water, power, and light, having regard to the great economy that can be exercised in constructing works on a large scale to supply a demand which is known in advance, and to the saving in heavy costs for land and promotion.

Where a rapid growth of population can be relied on and the site obtained at agricultural rates, it is evident that enormous profits can be made by the creation of new towns. 